\title{
TUBERCULOSIS INCIDENCE IN PATIENTS WITH HUMAN IMMUNODEFICIENCY VIRUS, TREATED WITH ISONIAZID FOR LATENT TUBERCULOSIS INFECTION
}

Claudia Teresa Vieira de Souza ${ }^{1}$, Maria de Lourdes Benamor Teixeira', Maria Isabel Fragoso da Silveira Gouvêa ${ }^{1}$, Jacob Milnor ${ }^{2}$, Jose Berilo de Lima Filho ${ }^{3}$, Marcel de Souza Borges Quintana ${ }_{4}^{4}$ and Valéria Cavalcanti Rolla ${ }^{5}$

\section{ABSTRACT}

Tuberculosis is the leading cause of death amongst adults with human immunodeficiency virus (HIV) infection. The lifetime risk of tuberculosis disease for a person with latent infection is estimated at 5-10\% with most cases occurring within five years of initial infection. The World Health Organization recommends isoniazid preventive therapy (IPT) for latent tuberculosis treatment, amongst other strategies. The aim was to assess tuberculosis incidence, survival (free of tuberculosis) and associated factors in HIV-positive patients. IPT was offered to participants with a positive $(\geq 5 \mathrm{~mm})$ tuberculin skin test. Participants were followed from February 2003-December 2016. Kaplan-Meier was used for survival analysis. Variables with $\mathrm{p}$-value $\leq 0.2$ in the univariate analysis entered into the multivariate Cox-Model, keeping those with $\mathrm{p}$-value $\leq 0.05$. The $95 \%$ confidence interval of incidence of tuberculosis was estimated using Poisson distribution. One hundred nineteen patients completed the IPT and were followed for a median duration of 110.7 months (IQR 93.1-121.0). The probability of developing tuberculosis (10 years post-IPT) was 5.4\%. Tuberculosis incidence was 0.58/100 patient/years (CI 95\% 0.213-1.264). IPT over 6 months provided long-term protection against tuberculosis. AIDS-defining illness was the only statistically significant variable $(\mathrm{HR}=5.67)$ in the multivariate model.

KEY WORDS: Latent tuberculosis; HIV; isoniazid; survival analysis.

\footnotetext{
1. Fiocruz, Instituto Nacional de Infectologia Evandro Chagas (INI), Laboratório de Pesquisa em Epidemiologia e Determinação Social da Saúde, Rio de Janeiro, RJ, Brazil.

2. Fiocruz, Instituto Oswaldo Cruz, Rio de Janeiro, RJ, Brazil.

3. Fiocruz, INI, Serviço de Informação e Estatística, Rio de Janeiro, RJ, Brazil.

4. Fiocruz, INI, Plataforma de Pesquisa Clínica, Rio de Janeiro, RJ, Brazil.

5. Fiocruz, INI, Laboratório de Pesquisa Clínica em Micobacterioses, Rio de Janeiro, RJ, Brazil.
}

Claudia Teresa Vieira de Souza: https://orcid.org/0000-0003-3208-722X; Maria de Lourdes Benamor Teixeira: https://orcid. org/0000-0002-6896-0089; Maria Isabel Fragoso da Silveira Gouvêa: https://orcid.org/0000-0002-1772-1942; Jacob Milnor: https://orcid.org/0000-0003-3515-4360; Jose Berilo de Lima Filho: https://orcid.org/0000-0001-5338-9636; Marcel de Souza Borges Quintana: https://orcid.org/0000-0001-5186-9791; Valéria Cavalcanti Rolla: https://orcid.org/0000-0002-0841-1408 


\section{INTRODUCTION}

Tuberculosis is the leading cause of death among adults with human immunodeficiency virus (HIV) infection (WHO, 2018). The lifetime risk of developing active tuberculosis disease from a latent tuberculosis infection (LTBI) is estimated at 5 to $10 \%$, with the majority of cases occurring within the first five years (WHO, 2018). The annual risk of TB disease due to reactivation of LTBI for people living with HIV without ART (antiretroviral therapy) has been estimated as $3 \%$ to $16 \%$ per year, which approximates the lifetime risk of TB disease for persons with LTBI who are HIV negative. However, even with the beneficial effects of ART, the risk of TB disease in this sub-population remains high and is greater than that of the general population (NIH, 2019). The use of isoniazid to prevent the development of active tuberculosis in HIV positive individuals with LTBI is one of the strategies recommended by the World Health Organization (WHO, 2018), the European Respiratory Society, the European Centre for Disease Prevention and Control (Migliori et al., 2018), the National Institute for Health and Care Excellence-United Kingdom (NICE) (NICE, 2019) and the Centers for Diseases Control and Prevention (CDC) (CDC, 2020). A recent meta-analysis has shown that isoniazid preventive therapy (IPT) given with ART reduces the risk of developing active tuberculosis by nearly one third when compared with ART alone in people living with HIV (Ross et al., 2021). Optimal duration of isoniazid use for LBTI treatment remains controversial. Some guidelines (WHO, 2018; Migliori et al., 2018; NICE, 2019), including the Brazilian Ministry of Health, have recommended regimens of 6 or 9 months of isoniazid use for LTBI treatment (MS, 2020). Samandari demonstrated that in a tuberculosis-endemic setting in Botswana, 36 months of isoniazid prophylaxis is more effective for tuberculosis prevention than 6-9 months for HIV positive individuals (Samandari et al., 2015). The results of this trial changed WHO recommendations in favor of a longer period of IPT (WHO, 2018). However, this strategy is hard to enforce when patients are feeling well and do not complain of any symptoms. This may result in a lack of motivation for prolonging chemoprophylaxis and consequently lead to low adherence and less effectiveness.

The Evandro Chagas National Institute of Infectious Diseases (INI - Fiocruz) is a federal reference institution for HIV patients. From 2002 to 2007, a study was conducted to evaluate the IPT effectiveness amongst HIV positive adults. The study showed that isoniazid $300 \mathrm{mg}$ QD was a safe and effective prevention option for HIV-tuberculosis co-infected patients (Souza et al., 2009). After the study, these same participants were followed in order to evaluate tuberculosis disease-related outcomes. The aim of the present study was to analyze tuberculosis incidence, patient survival [tuberculosis free time] and associated factors. 


\section{MATERIAL AND METHODS}

The study population included patients who had participated in the previous project (recruited from August 2002-April 2007). As mentioned, IPT was offered to HIV patients with a positive ( $\geq 5 \mathrm{~mm}$ ) tuberculin skin test (Souza et al., 2009). The participants were followed from February 2003 to December 2016.

Socio-demographic characteristics (gender, age, educational level, ethnicity and alcohol or tobacco use), lab results, immunological (CD4 count [cells/ $\mu \mathrm{L}]$ ) before and after use of IPT, CD4 nadir, viral load (VL-copies/ $\mathrm{mL}$ ) at start of IPT, history of antiretroviral use (ART) and comorbidities (ex. diabetes, or AIDS-defining conditions) (Schneider et al., 2008) were extracted from the records and data set in the previous study.

The use of a tuberculosis treatment regimen due to either clinical or lab-based diagnosis (smear and/or/positive culture for Mycobacterium tuberculosis) was the criterion for active tuberculosis disease determination.

The time free of tuberculosis was defined as the time, in months, from the end of IPT to either the development of active tuberculosis disease or some form of censoring (i.e. non-occurrence of the outcome event, death including from tuberculosis or loss to follow-up).

The Kaplan-Meier method was used to calculate the probability of survival during 10 years of follow-up. Observed curves were then compared by using the log-rank test. Hazard proportion Cox models were applied for univariate and multivariate analyses. To construct the multivariate model, we selected the univariate predictors with $p$-values $\leq 0.20$. Due to their plausibility, sex and age variables were included in the final model regardless of their significance. For the remaining predictors, those with $\mathrm{p}$-values $\leq 0.05$ were not discarded. Tuberculosis incidence was established using the Poisson distribution to estimate $95 \%$ confidence intervals. The analysis used SPSS software (IBM Corp, 2016) and the R version 4.0.4 (R Project, 2021).

The Ethics Committee of the Evandro Chagas National Institute of Infectious Diseases-Fiocruz approved the study protocol (number 000011/00902). All participants signed an informed consent form.

\section{RESULTS}

From August 2002 to April 2007, 138 patients were recruited and treated with IPT. During the follow up period, 19 participants did not complete IPT use (ten dropped out, seven stopped IPT use due to adverse events and two patients were lost during follow up). One hundred nineteen patients completed the isoniazid regimen and were followed for a median duration of 110.7 months (IQR 93.1-121.0), or 9.2 years (Table 1). 
Table 1. Sociodemographic and clinical characteristics of study population

\begin{tabular}{|c|c|}
\hline Total & $\begin{array}{c}\mathrm{n}(\%) \\
119(100)\end{array}$ \\
\hline \multicolumn{2}{|l|}{ Tuberculosis $(\mathrm{N}=119)$} \\
\hline Yes & $6(5)$ \\
\hline CD4 Nadir (cell/ $\mu \mathrm{L})$ Median (IQR) & $254(160-375)$ \\
\hline \multicolumn{2}{|l|}{ CD4 Nadir $($ cell $/ \mu \mathrm{L})$} \\
\hline$<200$ & $51(42.9)$ \\
\hline$\geq 200$ & $68(57.1)$ \\
\hline CD4 before IPT ${ }^{\mathrm{a}}($ cell $/ \mu \mathrm{L})$ Median (IQR) & $552(403-707)$ \\
\hline \multicolumn{2}{|l|}{$\mathrm{CD}^{2}$ before $\mathrm{IPT}^{1}(\mathrm{cell} / \mu \mathrm{L})$} \\
\hline$<500$ & $51(43.6)$ \\
\hline$\geq 500$ & $66(56.4)$ \\
\hline $\mathrm{CD}$ after IPT ${ }^{\mathrm{a}}(\operatorname{cell} / \mu \mathrm{L})$ Median (IQR) & $546(363-705)$ \\
\hline \multicolumn{2}{|l|}{ CD4 after IPT $($ cell $/ \mu \mathrm{L})$} \\
\hline$<500$ & $53(44.5)$ \\
\hline$\geq 500$ & $66(55.5)$ \\
\hline \multicolumn{2}{|l|}{ Ethnicity } \\
\hline Not white & $56(47.1)$ \\
\hline White & $63(52.9)$ \\
\hline \multicolumn{2}{|l|}{ Alcohol } \\
\hline Yes & $44(37)$ \\
\hline No & $75(63)$ \\
\hline \multicolumn{2}{|l|}{ Diabetes } \\
\hline No & $90(75.6)$ \\
\hline Yes & $29(24.4)$ \\
\hline \multicolumn{2}{|l|}{ Formal education } \\
\hline$\leq 8$ years & $54(45.4)$ \\
\hline$>8$ years & $65(54.6)$ \\
\hline \multicolumn{2}{|l|}{ Tobacco } \\
\hline Yes & $65(54.6)$ \\
\hline No & $54(45.4)$ \\
\hline \multicolumn{2}{|l|}{ Age } \\
\hline$<35$ years & $89(74.8)$ \\
\hline$\geq 35$ years & $30(25.2)$ \\
\hline \multicolumn{2}{|l|}{ Sex } \\
\hline Male & $79(66.4)$ \\
\hline Female & $40(33.6)$ \\
\hline \multicolumn{2}{|l|}{ Antiretroviral therapy use $\mathrm{b}^{\mathrm{b}}$} \\
\hline Yes & $88(73.9)$ \\
\hline No & $31(26.1)$ \\
\hline \multicolumn{2}{|l|}{ AIDS-defining conditions ${ }^{c}$} \\
\hline No & $93(78.2)$ \\
\hline Yes & $26(21.8)$ \\
\hline \multicolumn{2}{|l|}{ Viral load $(\text { copies } / \mathrm{mL})^{\mathrm{b}}$} \\
\hline$<200$ & $65(54.6)$ \\
\hline$\geq 200$ & $54(45.4)$ \\
\hline
\end{tabular}

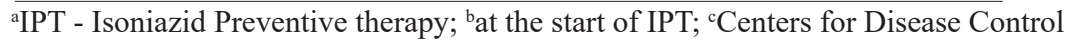
and Prevention 
Most patients were men (66.4\%). 54.6\% had more than 8 years of schooling. $52.9 \%$ were white; and the median age was 41 . Approximately $54.6 \%$ had viral loads under 200 at the start of IPT. $73.9 \%$ were taking ARVs as shown in Table 1 . The median CD4 cell count pre-IPT was 552 cells $/ \mu \mathrm{L}$ (IQR 403-707) and post IPT fell to 546 cells/ $\mu \mathrm{L}$ (IQR 363-706). The median CD4 nadir was 254 cells/ $\mu \mathrm{L}$ (IQR 160-375). Seven (6\%) died (one as a result of pulmonary tuberculosis). During the study follow up, six patients $(5 \%)$ developed active tuberculosis (four pulmonary and two extra-pulmonary - one disseminated and 1 laryngeal). All of them had CD4 cell count $>350$ cells $/ \mu \mathrm{L}$ and 5/6 patients were using ART at TB diagnosis.

In this study, the probability of developing tuberculosis within 10 years post-IPT was $5.4 \%$ (Figure 1).

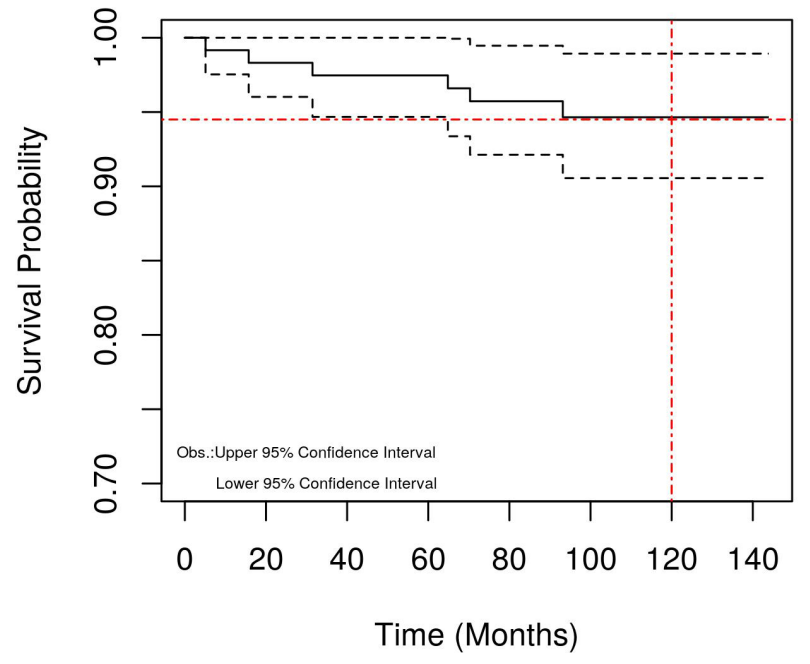

Figure 1. Kaplan Meier survival analysis - Probability of developing tuberculosis after Isoniazid Preventive Therapy $(\mathrm{n}=119)$.

Analysis did not capture median survival time probably due to the small number of tuberculosis related outcomes (Figure 1). Patients were followed for 13.9 years (February 4, 2003 to December 31, 2016). The incidence for this period was 1.59 cases of tuberculosis per 100.000 persons (95\% CI $0.58-3.46$ ), or 0.58 per 100 persons/years - PY (95\% CI $0.213-1.264)$. In the univariate Cox models, only age $[\mathrm{HR}=6.2(1.1 ; 33.9)]$ and having had at least one AIDS - defining illness $[\mathrm{HR}=7.6(1.3 ; 41.4]$ were associated with high risk of developing active tuberculosis. ARV use was not significant ( $\mathrm{p}$ value $=0.635$ ). In the multivariate model, having had at least one AIDS-defining illness was the only significant variable $(\mathrm{HR}=5.67[1.01 ; 31.78])$, even when controlled regarding gender and age (Table 2 and Figure 2). 
Table 2a. Crosstabulation, univariate and multivariate models for Tuberculosis infection.

\begin{tabular}{|c|c|c|c|c|c|c|}
\hline \multirow{2}{*}{ Variables } & \multicolumn{2}{|c|}{ Tuberculosis } & \multirow{2}{*}{ Probability (10 years) } & \multirow{2}{*}{$\mathrm{LR}^{\mathrm{d}}$} & \multicolumn{2}{|c|}{ Multivariate models } \\
\hline & No & Yes & & & Adjusted HR & $\mathrm{p}$-value \\
\hline \multirow[t]{2}{*}{ Total } & 113 & 6 & $0.95(0.91-0.99)$ & & & \\
\hline & $\mathrm{n}(\%)$ & n (\%) & & & & \\
\hline Sex & & & & 0.1 & & \\
\hline Male & 77 (97.5) & $2(2.5)$ & $0.97(0.94-1)$ & & 1 & \\
\hline Female & $36(90)$ & $4(10)$ & $0.9(0.81-1)$ & & $2.5(0.4-14.2)$ & 0.3 \\
\hline Age & & & & 0.0 & & \\
\hline$<35$ years & $87(97.8)$ & $2(2.2)$ & $0.97(0.94-1)$ & & 1 & \\
\hline$>=35$ years & $26(86.7)$ & $\begin{array}{l}4 \\
(13.3)\end{array}$ & $0.87(0.75-1)$ & & $4.19(0.7-23.9)$ & 0.1 \\
\hline Years of Education & & & & 0.2 & & \\
\hline$<=8$ years & $50(92.6)$ & $4(7.4)$ & $0.92(0.85-1)$ & & & \\
\hline$>8$ years & $63(96.9)$ & $2(3.1)$ & $0.97(0.93-1)$ & & & \\
\hline Ethnicity & & & & 0.3 & & \\
\hline No white & $52(92.9)$ & $4(7.1)$ & $0.92(0.86-1)$ & & & \\
\hline White & $61(96.8)$ & $2(3.2)$ & $0.97(0.92-1)$ & & & \\
\hline Alcohol & & & & 0.0 & & \\
\hline Yes & $44(100)$ & $0(0)$ & & & & \\
\hline No & $69(92)$ & $6(8)$ & $0.92(0.85-0.98)$ & & & \\
\hline Tobacco & & & & 0.3 & & \\
\hline Yes & $63(96.9)$ & $2(3.1)$ & $0.97(0.93-1)$ & & & \\
\hline No & $50(92.6)$ & $4(7.4)$ & $0.92(0.85-1)$ & & & \\
\hline Diabetes & & & & 0.6 & & \\
\hline No & $86(95.6)$ & $4(4.4)$ & $0.95(0.91-1)$ & & & \\
\hline Yes & $27(93.1)$ & $2(6.9)$ & $0.93(0.84-1)$ & & & \\
\hline
\end{tabular}

${ }^{a}$ IPT - Isoniazid Prophylactic therapy; ${ }^{b} C e n t e r s$ for Disease Control and Prevention; ${ }^{c}$ at the start of IPT; ${ }^{\mathrm{d}} \mathrm{LR}$ - Likelihood ratio. 
Table 2b. Crosstabulation, univariate and multivariate models for Tuberculosis infection.

\begin{tabular}{|c|c|c|c|c|c|c|}
\hline \multirow{4}{*}{ Variables } & \multicolumn{2}{|c|}{ Tuberculosis } & \multirow{4}{*}{ Probability (10 years) } & \multirow{4}{*}{$\mathrm{LR}^{\mathrm{d}}$} & \multicolumn{2}{|c|}{ Multivariate models } \\
\hline & No & Yes & & & Adjusted HR & $\mathrm{p}$-value \\
\hline & 113 & 16 & & & & \\
\hline & $\mathrm{n}(\%)$ & $\mathrm{n}(\%)$ & & & & \\
\hline CD4 (cells $/ \mu \mathrm{L})$ Nadir & & & & 0.1 & & \\
\hline$<200$ & $50(98)$ & $1(2)$ & $0.98(0.94-1)$ & & & \\
\hline$>=200$ & $63(92.6)$ & $5(7.4)$ & $0.92(0.86-0.99)$ & & & \\
\hline CD4 (cells $/ \mu \mathrm{L}$ ) before IPT ${ }^{\mathrm{a}}$ & & & & 0.2 & & \\
\hline$<500$ & $47(92.2)$ & $4(7.8)$ & $0.92(0.84-1)$ & & & \\
\hline$>=500$ & $64(97)$ & $2(3)$ & $0.97(0.93-1)$ & & & \\
\hline CD4 (cells $/ \mu \mathrm{L})$ after_IPT ${ }^{a}$ & & & & 0.0 & & \\
\hline$<500$ & $48(90.6)$ & $5(9.4)$ & $0.9(0.82-0.99)$ & & & \\
\hline$>=500$ & $65(98.5)$ & $1(1.5)$ & $0.98(0.96-1)$ & & & \\
\hline AIDS-defining conditions ${ }^{b}$ & & & & 0.0 & & \\
\hline No & $91(97.8)$ & $2(2.2)$ & $0.98(0.94-1)$ & & 1 & \\
\hline Yes & $22(84.6)$ & $\begin{array}{l}4 \\
(15.4)\end{array}$ & $0.84(0.71-1)$ & & $5.6(1.0-31.7)$ & $<0.05$ \\
\hline Viral load (copies $/ \mathrm{mL})$ near IPT & & & & 0.7 & & \\
\hline$<200$ & $62(95.4)$ & $3(4.6)$ & $0.95(0.9-1)$ & & & \\
\hline$>=200$ & $51(94.4)$ & $3(5.6)$ & $0.94(0.88-1)$ & & & \\
\hline Antiretroviral therapy use ${ }^{c}$ & & & & 0.6 & & \\
\hline Yes & $83(94.3)$ & $5(5.7)$ & $0.94(0.89-0.99)$ & & & \\
\hline No & $30(96.8)$ & $1(3.2)$ & $0.97(0.91-1)$ & & & \\
\hline
\end{tabular}

${ }^{\mathrm{a}}$ IPT - Isoniazid Prophylactic therapy; ${ }^{\mathrm{b} C e n t e r s ~ f o r ~ D i s e a s e ~ C o n t r o l ~ a n d ~ P r e v e n t i o n ; ~}{ }^{\mathrm{c}}$ at the start of IPT; ${ }^{\mathrm{L}} \mathrm{LR}$ - Likelihood ratio.

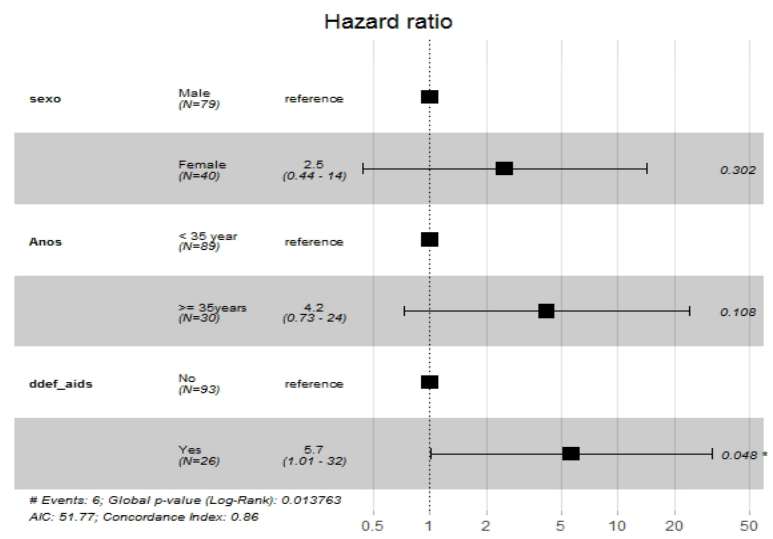

Figure 2. Confidence Intervals for the Hazard Ratios by predicting variable. $\mathrm{n}=119$ patients. 


\section{DISCUSSION}

HIV infection is a serious risk factor for activation of latent tuberculosis infection (Johnson et al., 2001) and many authors have endorsed IPT as an effective means of tuberculosis prevention (Golub et al., 2015; WHO, 2018). In a recent systematic review, focusing on isoniazid prophylactic therapy for prevention of tuberculosis in HIV-positive adults, IPT was associated with preventing active tuberculosis (Ayele et al., 2015). A persisting question within the medical community is how long patients are protected from active tuberculosis by IPT. In this study, during follow up, 5\% of the participants developed tuberculosis, with one patient dying as a result and the probability of developing tuberculosis within 13 years post-IPT was $5.4 \%$. In another Brazilian study, de Pinho et al. (2001), 5\% of participants who used IPT for 6 months also developed active tuberculosis; with a median follow-up time of 43.6 months. Golub et al. (2015) also showed that a 6-month regimen of IPT reduced tuberculosis risk for as long as 7 years among TST-positive, HIVpositive patients in Brazil, regardless of ART use. The incident rate found in Golub's study, 0.53/100 person-years (PY), was similar to that found in our study ( 0.58 per 100 PY during 13 years). However, the impact of ITP on incidence rate may be different in other settings with higher incidence rates of tuberculosis infection, due to the high probability of reinfection (Gupta et al., 2012; Suthar et al., 2012; TEMPRANO et al., 2015).

In the univariate Cox models, only age and having had at least one AIDS defining illness were associated with high risk of developing active tuberculosis. In contrast to other studies, this showed that ART use had an impact on tuberculosis risk for this study. ART use was not associated with the reduction of tuberculosis incidence (Golub et al., 2007; Golub et al., 2009; Rangaka et al, 2014). This finding may be explained by our only considering ART use at the time of IPT initiation. Therefore, the potential benefits of starting ART use after IPT may not have been detected. CD4 cell count (cells $/ \mu \mathrm{L}$ ) at start of IPT was also not associated with a reduction in tuberculosis incidence. In fact, CD4 cell count may have fluctuated during patient follow-up.

This analysis suggests that in settings such as Rio de Janeiro state, IPT given for 6 months provides long-term protection against tuberculosis. Although the study consisted of a small sample, the main strength of this study was the length of follow up time (median of 9.2 years) when compared to other similar studies with shorter periods.

In the multivariate model, having had at least one AIDS defining illness was the only significant variable, even when controlled by the variables gender and age. This is expected as an AIDS defining illness is always associated with an immunosuppression status, which is also related with risk for tuberculosis infection. 
In conclusion, the tuberculosis incidence was 1.59 cases of tuberculosis per 100,000 patients or 0.58 per 100 PY. The probability of developing tuberculosis within 10 years post-IPT was $5.4 \%$. The occurrence of very few events suggests that IPT strategy was satisfactory in preventing tuberculosis during the follow up period of this study. Our analysis suggests that in similar settings, IPT given for 6 months provides long-term protection against tuberculosis.

Having had at least one AIDS defining illness was the only statistically significant variable $(\mathrm{HR}=5.67)$ in the multivariate model.

Further studies focusing on the type of prophylactic regimens and on duration of the protective effect of treatment of latent tuberculosis in HIV subpopulation are necessary.

\section{CONFLICT OF INTEREST}

The authors declare no conflicts of interest

\section{REFERENCES}

1. Ayele HT, Mourik MSM van, Debray TPA, Bonten MJM. Isoniazid Prophylactic Therapy for the Prevention of Tuberculosis in HIV Infected Adults: A Systematic Review and MetaAnalysis of Randomized Trials. PloS One 10: e142290, 2015.

2. CDC. Centers for Disease Control and Prevention. Treatment Regimens for Latent TB Infection. Treatment. TB. February 2020. Available at: https://www.cdc.gov/mmwr/volumes/69/rr/ rr6901a1.htm?s_cid=rr6901a1_w $>$ Access in: 17 mar. 2021.

3. de Pinho AM, Santoro-Lopes G, Harrison LH, Schechter M. Chemoprophylaxis for tuberculosis and survival of HIV-infected patients in Brazil. AIDS 15: 2129-2135, 2001.

4. Golub JE, Cohn S, Saraceni V, Cavalcante SC, Pacheco AG, Moulton LH, Durovini B, Chaisson RE. Long-term protection from isoniazid preventive therapy for tuberculosis in HIVinfected patients in a medium-burden tuberculosis setting: the TB/HIV in Rio (THRio) study. Clin Infect Dis 60: 639-645, 2015.

5. Golub JE, Pronyk P, Mohapi L, Thsabangu N, Moshabela M, Struthers H, Glenda E, Gray GE, Mclintyre JA, Chaisson RE, Martinson NA. Isoniazid preventive therapy, HAART and tuberculosis risk in HIV-infected adults in South Africa: a prospective cohort. AIDS 23: 631636, 2009.

6. Golub JE, Saraceni V, Cavalcante SC, Pacheco AG, Moulton LH, King BS, Efron A, Moore $\mathrm{RD}$, Chaisson RE, Durovini B. The impact of antiretroviral therapy and isoniazid preventive therapy on tuberculosis incidence in HIV-infected patients in Rio de Janeiro, Brazil. AIDS 21: 1441-1448, 2007.

7. Gupta A, Wood R, Kaplan R, Bekker L-G, Lawn SD. Tuberculosis incidence rates during 8 years of follow-up of an antiretroviral treatment cohort in South Africa: comparison with rates in the community. PloS One 7: e34156, 2012.

8. IBM Corp. Released 2016. IBM SPSS Statistics for Windows, Version 24.0. Armonk, NY: IBM Corp. 
9. Johnson JL, Okwera A, Hom DL, Mayanja H, Mutuluuza Kityo C, Nsubuga P, Loughlin AM, Yun H, Mugyenyi PN, Vernon A, Mugerwa RD, Ellner JJ, Whalen CC, UgandaCase Western Reserve University Research Collaboration. Duration of efficacy of treatment of latent tuberculosis infection in HIV-infected adults. AIDS 15: 2137-2147, 2001.

10. Migliori GB, Sotgiu G, Rosales-Klintz S, Centis R, D’Ambrosio L, Abubakar I, Bothamley G, Caminero JA, Cirillo DM, Dara M, de Vries G, Aliberti S, Dinh-Xuan AT, Duarte R, Midulla F, Solovic I, Subotic DR , Amicosante M, Correia AM, Cirule A, Gina Gualano G, Kunst H, Palmieri F, Riekstina V, Tiberi S, Verduin R , van der Werf MJ. ERS/ECDC Statement: European Union standards for tuberculosis care, 2017 update. Eur Respir J 51:1702678, 2018.

11. MS. Ministério da Saúde. Brasil. Secretaria de Vigilância em Saúde Departamento de Vigilância das Doenças Transmissíveis Coordenação-Geral do Programa Nacional de Controle da Tuberculose. Protocolo de vigilância da infecção latente pelo Mycobacterium tuberculosis no Brasil. June 2020. Available at: <http://www.aids.gov.br/pt-br/pub/2018/protocolo-devigilancia-da-infeccao-latente-pelo-mycobacterium-tuberculosis-no-brasil> Access in: 21 jun. 2021.

12. NIH. National Institutes of Health. Mycobacterium tuberculosis Infection and Disease. April 2021. Available at: <https://clinicalinfo.hiv.gov/en/guidelines/adult-and-adolescentopportunistic-> Access in: 21 jun. 2021.

13. NICE. National Institute for Health and Care Excellence. Tuberculosis Guidance and guidelines. September 2019. Available at: < https://www.nice.org.uk/guidance/ng33/chapter/ Recommendations\#latent-tb> Access in: 17 mar. 2021.

14. R Project. The R Project for Statistical Computing. March 2021. Available at: <https://www.rproject.org/> Access in: 10 apr. 2021.

15. Rangaka MX, Wilkinson RJ, Boulle A, Glynn JR, Fielding K, van Cutsem G, Wilkinson KA, Goliath R, Mathee S, Goemaere E, Maartens G. Isoniazid plus antiretroviral therapy to prevent tuberculosis: a randomised double-blind, placebo-controlled trial. Lancet 384: 682-690, 2014.

16. Ross JM, Badje A, Rangaka MX, Walker AS, Shapiro AE, Thomas KK, Anglaret X, Eholie S, Gabillard D, Boulle A, Maartens G, Wilkinson RJ, Ford N, Golub JE, Williams BG, Barnabas RV. Isoniazid preventive therapy plus antiretroviral therapy for the prevention of tuberculosis: a systematic review and meta-analysis of individual participant data. Lancet HIV 8: e8-e15, 2021.

17. Samandari T, Agizew TB, Nyirenda S, Tedla Z, Sibanda T, Mosimaneotsile B, Motsamai OI, Shang N, Rose CE, Shepherd J. Tuberculosis incidence after 36 months' isoniazid prophylaxis in HIV-infected adults in Botswana: a post-trial observational analysis. AIDS 29: 351-359, 2015.

18. Schneider E, Whitmore S, Glynn KM, Dominguez K, Mitsch A, McKenna MT, CDC. Revised surveillance case definitions for HIV infection among adults, adolescents, and children aged $<18$ months and for HIV infection and AIDS among children aged 18 months to $<13$ years-United States, 2008. MMWR Recomm Rep 57: 1-12, 2008.

19. Souza CTV, Hökerberg YHM, Pacheco SJB, Rolla VC, Passos SRL. Effectiveness and safety of isoniazid chemoprophylaxis for HIV-1 infected patients from Rio de Janeiro. Mem Inst Oswaldo Cruz 104: 462-467, 2009.

20. Suthar AB, Lawn SD, del Amo J, Getahun H, Dye C, Sculier D, Sterling TR, Chaisson RE, Williams BG, Harries AD, Granich RM. Antiretroviral therapy for prevention of tuberculosis in adults with HIV: a systematic review and meta-analysis. PLoS Med 9: e1001270, 2012. 
21. TEMPRANO ANRS 12136 Study Group, Danel C, Moh R, Gabillard D, Badje A, Le Carrou J, Ouassa T, Ouattara E, Anzian A, Ntakpé JB, Minga A, Kouame GM, Bouhoussou F, Emieme A, Kouamé A, Inwoley A, Toni TD, Ahiboh H, Kabran M, Rabe C, Sidibé B, Nzunetu G, Konan R, Gnokoro J, Gouesse P, Messou E, Dohoun L, Kamagate S, Yao A, Amon S, Kouame AB, Koua A, Kouamé E, Ndri Y, Ba-Gomis O, Daligou M, Ackoundzé S, Hawerlander D, Ani A, Dembélé F, Koné F, Guéhi C, Kanga C, Koule S, Séri J, Oyebi M, Mbakop N, Makaila O, Babatunde C, Babatounde N, Bleoué G, Tchoutedjem M, Kouadio AC, Sena G, Yededji SY, Assi R, Bakayoko A, Mahassadi A, Attia A, Oussou A, Mobio M, Bamba D, Koman M, Horo A, Deschamps N, Chenal H, Sassan-Morokro M, Konate S, Aka K, Aoussi E, Journot V, Nchot C, Karcher S, Chaix ML, Rouzioux C, Sow PS, Perronne C, Girard PM, Menan H, Bissagnene E, Kadio A, Ettiegne-Traore V, Moh-Semdé C, Kouame A, Massumbuko JM, Chêne G, Dosso M, Domoua SK, N'Dri-Yoman T, Salamon R, Eholié SP, Anglaret X. A Trial of Early Antiretrovirals and Isoniazid Preventive Therapy in Africa. N Engl J Med 373: 808$822,2015$.

22. WHO. World Health Organization. Latent tuberculosis infection (LTBI) - April 2020. Available at: <http://www.who.int/tb/areas-of-work/preventive-care/ltbi_faqs/en/> Access in: 30 mar. 2021. 